\begin{tabular}{|c|c|c|}
\hline institute & $\begin{array}{l}\text { CARADDE: Jurnal Pengabdian Kepada Masyarakat } \\
\text { https://journal.ilininstitute.com/index.php/caradde } \\
\text { Volume } 2 \text { | Nomor 1 | Agustus | 2019 } \\
\text { e-ISSN: } 2621-7910 \text { dan p-ISSN: } 2621-7961 \\
\text { DOI: https://doi.org/10.31960/caradde.v2i1.119 }\end{array}$ & $\begin{array}{l}\text { IIin } \\
\text { garagd }\end{array}$ \\
\hline
\end{tabular}

\title{
Pengabdian Kepada Masyarakat Dalam Sinergitas Akademisi Dan TNI Bersama Tangkal Hoax Dan Black Campaign
}

\author{
Susanto ${ }^{1}$, Muhamad Iqbal ${ }^{2}$
}

\begin{tabular}{ll}
\hline Keywords : & Abstrak Pengabdian Kepada Masyarakat (PKM) ini bertujuan \\
Pengabdian Masyarakat; & untuk membangun sinergi akademis antara Dosen Universitas \\
Akademisi dan TNI; & Pamulang dengan Jajaran TNI KODIM/0506 Tangerang. \\
Hoax dan Black Campaign. & BErkaitan tentang pemahaman mendalam tentang makna hoax \\
& dan black Campaign yang merupakan fenomena serius yang \\
Corespondensi Author & harus diantisipasi, guna menunjang pelaksanaan upaya \\
Hukum, Fakultas Hukum & pencegahan dan meminimalisir dampak dari kedua hal tersebut. \\
Universitas Pamulang & Metode pelaksanaan dalam penelitian ini ialah dengan cara \\
Email: & survey dan kita mendatangai KODIM 0506/TGR, Jalan Tmp \\
& Taruna, Sukasari, Kec. Tangerang, Kota Tangerang dan akan \\
History Artikel & memberikan materi dan pelatihan disana. Bahwa dari hal \\
Received: Januari-2019; & tersebut hasil dari PKM ini adalah terbangunya satu persepsi \\
Reviewed: April-2019 & tentang sinergitas akademis antara Dosen Universitas Pamulang \\
Accepted: April-2019 & dengan Jajaran TNI KODAM 0506/Tangerang tentang makna \\
Published: Juni-2019 & hoax dan black Campaign serta upaya penangan pertama \\
& berkaitan dengan hal tersebut. Oleh karenanya media ini \\
& dikembangkan dan berkembang di dalam masyarakat dan \\
& berbentuk diskusi terbuka sehingga secara tidak langsung dapat \\
& menimbulkan paham paham maupun pengetahuan baru di \\
& dalam masyarakat dengan atau tanpa bukti yang jelas.
\end{tabular}

(1) This work is licensed under a Creative Commons Attribution 4.0 International License

\section{PENDAHULUAN}

Kota Tangerang adalah sebuah kota yang terletak di Tatar Pasundan Provinsi Banten, Indonesia. Kota ini terletak tepat di sebelah barat ibu kota negara Indonesia, Jakarta. Kota Tangerang berbatasan dengan Kabupaten Tangerang di sebelah utara dan barat, Kota Tangerang Selatan di sebelah selatan, serta Daerah Khusus Ibukota Jakarta di sebelah timur. Tangerang merupakan kota terbesar di Provinsi Banten serta ketiga terbesar di kawasan Jabodetabek setelah Jakarta dan Bekasi di provinsi Jawa Barat.

Berkaitan dengan tema yang diangkat diatas, dala konteks ini tantangan dari sebuah kota besar ialah stabilitas ketertiban di masyarakatnya, mengingat banyak fasilitasfasilitas penting yang berada di wilayah tersebut. Salah satu tantangan bebsar yang berpotensi terjadi di kota-kota besar yang salah satunya ialah Kota Tangerang adalah penyebaran Hoax dan Black Campaign, yang kini sedang populer mendekati perhelatan politik besar di Indonesia yakni Pilpres dan Pileg. Hoax dan Black Campaign dihadapkan dengan Stabilitas Ketertiban masyarakat adalah beberapa hal yang bertolak belakang, hal tersebut di karenakan Hoax dan Black Campaign bisa menjadi ancaman terbesar bagi Stabilitas Ketertiban di Masyarakat, bila mana tidak langsung di tangkal. Oleh karena hal tersebut Pengabdian Kepada Masyarakat kali ini akan berfokus pada upaya kesiapan dan 
Caradde: Jurnal Pengabdian Kepada Masyarakat

Vol 2 No 1, Agustus 2019

antisipasi atas isue Hoax dan Black Campaign tersebut. Hoax adalah kabar, informasi, berita palsu atau bohong. Sedangkan dalam KBBI disebut dengan hoax yang artinya berita bohong (KBBI Daring, 2019). Hoax merupakan ekses negatif kebebasan berbicara dan berpendapat di internet. Khususnya media sosial dan blog (Herlinda, 2019). Sehingga dalam hal ini kita dapat mengambi gambaran bahwa hoax adalah usaha untuk menipu atau mengakali pembaca/pendengarnya untuk mempercayai sesuatu, padahal sang pencipta berita palsu tersebut tahu bahwa berita tersebut adalah palsu. Hoax bertujuan membuat opini publik, menggiring opini, membentuk persepsi, juga untuk bersenang-senang yang menguji kecerdasan dan kecermatan pengguna internet dan media sosial.

Black Campaign atau Kampanye hitam sebuah cara untuk menjunjung harkat dan martabat pasangan calon dengan mempertaruhkan lawannya yang dijatuhkan. Menurut Cangara (2014) setiap usaha untuk mengisi jabatan, terutama untuk jabatan publik, maka gossip yang mengarah pada bentuk kampanye hitam selalu muncul. Kampanye hitam yang biasa disebut black campaign cenderung menyudutkan para calon yang diusung untuk menduduki suatu jabatan. Isu itu biasanya erat kaitannya dengan apa yang disebut "3Ta", yaitu : Harta, Wanita, dan Tahta. Harta biasanya diisukan dalam bentuk korupsi, wanita dalam bentuk istri simpanan atau perselingkuhan, sedangkan tahta dinilai sikap ambisius.

Tujuan Umum dari PKM ini adalah meningkatkan pengetahuan dan kemampuan audiens untuk mencegah dan menangkal Hoax dan Black Campaign di masyarakat. Tujuan Khusus dari PKM ini adalah berupaya Meningkatkan pengetahuan audiens PKM tentang bahaya Hoax dan Black Campaign, setalah meningkatkan pengetahuan dasar audiens tentang tema yang akan di gunakan maka tapa selanjutnya adalah berupaya serupa pada konteks pengetahuan dan kemampuan audiens PKM yang berkaitan dengan upaya menditeksi secara dini penyebaran Hoax dan Black Campaign dan mencegah dampak buruknya, selanjutnya berupaya eningkatkan kemampuan audiens PKM dalam hal mempromosikan dan mensosialisasikan berkaitan penggunaan media sosial yang bijak dan benar, serta memberikan motivasi kepada audiens PKM berkaitan dengan upaya pervensi dan mencegah penyebaran terhadap Hoax dan Black Campaign di Masyarakat.

Berkaitan dengan hal tersebut dalam hal ini Persepsi adalah inti komunikasi, sedangkan penafsiran (interpretasi) adalah inti persepsi, yang identic dengan dengan penyandian-balik (decoding) dalam proses komunikasi. Hal ini jelas tampak pada definisi John R. Wenburg dan William W. Wilmot: “ Persepsi dapat didefinisikan sebagai cara organisme memberi makna", Rudolph F. atau J. Cohen: " Persepsi didefinisikan sebagai interpretasi bermakna atas sensasi sebagai representative objek eksternal; persepsi adalah pengetahuan yang tampak mengenai apa yang ada di luar sana Persepsi disebut inti komunikasi, karena jika persepsi kita tidak akurat, tidak mungkin kita berkomunikasi dengan efektif (Mulyana \& Deddy, 2014).

Dalam hal ini Persepsilah yang menentukan kita memilih suatu pesan dan mengabaika pesan yang lain. semakin tinggi derajat kesamaan persepsi antarindividu, semakin muda dan semakin sering merka berkomunikasi, dan sebagai konsekuensinya semakin cenderung mrembentuk kelompok budaya atau kelompok identitas. Dalam konteks tersebut dimana konteks kelemahan dari komunikasi ialah persepsi yang tidak akurat namun menarik untuk dipilih sebagai acuan. Maka akan mengarah pada manipulasi sepeti hoax. Istilah hoax sendiri berarti tipuan atau lelucon. Kegiatan menipu, rencana menipu, trik menipu, disebut dengan hoax (Cambridge Dictionary, 2019). Pada situs hoaxes.org dalam konteks budaya mengarah pada pengertian hoax sebagai aktifitas menipu: Ketika sebuah surat kabar dengan sengaja mencetak cerita palsu, kami menyebutnya tipuan. Kami juga menggambarkan aksi publisitas yang menyesatkan, ancaman bom palsu, penipuan ilmiah, penipuan bisnis, dan klaim politik palsu sebagai tipuan. Konteks tersebut mengingat bahwa Hoax bertujuan membuat opini publik, menggiring opini, membentuk persepsi, juga untuk bersenangsenang yang menguji kecerdasan dan kecermatan pengguna internet dan media sosial. Hoax dibuat seseorang atau kelompok dengan beragam tujuan, mulai dari sekedar main-main, hingga tujuan ekonomi (penipuan), dan politik (propaganda/pembentukan opini publik) atau 
agitasi (hasutan). Hoax biasanya muncul ketika sebuah isu mencuat ke permukaan, namun banyak hal yang belum terungkap atau menjadi tanda tanya.

Menurut Cangara (2014) setiap usaha untuk mengisi jabatan, terutama untuk jabatan publik, maka gossip yang mengarah pada bentuk kampanye hitam selalu muncul. Kampanye hitam yang biasa disebut black campaign cenderung menyudutkan para calon yang diusung untuk menduduki suatu jabatan. Isu itu biasanya erat kaitannya dengan apa yang disebut "3Ta", yaitu : Harta, Wanita, dan Tahta. Harta biasanya diisukan dalam bentuk korupsi, wanita dalam bentuk istri simpanan ataum perselingkuhan, sedangkan tahta dinilai sikap ambisius.

Sedangkan Konteks Black Seperti yang diungkapkan oleh Pierre Levy (1997) dalam bukunya Cyberculture, the internet adalah lingkungan informasi yang terbuka, fleksibel, dan dinamis memungkinkan orang untuk mengembangkan orientasi pengetahuan baru. Orang-orang terlibat dalam dunia yang demokratis yang mempromosikan berbasis masyarakat yang lebih interaktif alokasi kekuasaan. Ranah daring bertindak sebagai semacam tempat pertemuan orang untuk memperluas ruang sosial mereka, menciptakan peluang untuk yang baru pengetahuan, dan menawarkan ruang untuk berbagi pandangan yang berbeda secara luas (Soukup, 2006: 423). "

Terry Cooper (1991) Iklan kampanye negatif adalah serangkaian iklan yang berisi segala sesuatu yang bersifat persuasif untuk menyerang kekuatan lawan dengan menunjukkan berbagai kelemahannya berdasarkan data dan fakta yang ada. Sementara itu Gina M. Garrmone (1984) berpendapat bahwa Kampanye iklan negatif merupakan iklan politik yang berisi hal-hal yang bersifat menyerang (attacks) kepada personalitas kandidat lainnya atau partai politik dari kandidat tertentu dengan menggunakan isu tertentu.

\section{METODE}

Metode pelaksanaan dalam penelitian ini ialah dengan cara survey dan kita mendatangai KODIM 0506/TGR, Jalan Tmp Taruna, Sukasari, Kec. Tangerang, Kota Tangerang dan akan memberikan materi dan pelatihan disana.
Materi yang di berikan berkaitan dengan urgensi penangklan hoax dimasyarakat dan Black Campaign. Pelatihan yang di berikan dalam PKM tersebut ialah pelatihan dalam hal memahami maksud dan tujuan keberadaan dan disebarnya hoax dan Black Campaign di masyarakat. Serta cara memilah-milah informasi tersebut. Serta diakhir dijeaskan pula tentang konsekuensi hukum dari kedua hal tersebt bila mana sengaja dilakukan. Hal tertsebut guna menanamkan jiwa anti hoax dan Black Campaign pada diri masing-masing audiens PKM. Yang diharapkan dari audiensaudiens tersebut akan menjadi kader-kader yang akan pula memberikan sosialisasi di masyarakat tentang dampak negatif hoax dan Black Campaign tersebut.

Adapun jenis data yang akan digunakan dalam penelitian ini beberapa diataranya adalah, Penggunaan data primer yakni data-data atau sumbersumber yang mengikat yang terdiri dari Tiga Koran, yaitu Kompas, Jawa Pos, dan Kedaulatan Rakyat. Selanjutnya adalah penggunaan data Sekunder adalah data yang berupa dokumen-dokumen resmi, buku-buku hasil penelitian yang berwujud laporan, buku harian dan lain-lain (Soekarno,2009). Dalam hal ini penggunaan tekhnik pengumpulan data yang digunakan dalam penelitian ini adalah mengunakan dokumentasi dan kepustakaan. Tekhnik dokumentasi adalah teknik yang dilakukan untuk mendapatkan dokumen. Yang dimaksud dokumen adalah setiap bahan yang tertulis. Yang dimaksud dengan bahan tertulis dalam penelitian ini adalah berita-berita yang ada ditiga Media, yakni Kompas, Jawa Pos, dan Kedaulatan Rakyat yang berkaitan dengan kampanye hitam pada pilpres tahun 2014. Sedangkan tekhnik pengumpulan data yang lain, yakni menggunakan studi kepustakaan. Menurut Nasution dalam bukunya "Metode Research" mengemukakan bahwa yang dimaksud dengan studi kepustakaan adalah tekhnik pengumpulan data dengan mengadakan studi penelaahan terhadap bukubuku, literatur-literatur, catatan-catatan, dan laporan-laporan yang ada hubunganya dengan masalah yang akan dipecahkan atau diteliti.

\section{HASIL DAN PEMBAHASAN}

\section{a. Kajian Hoax}

Hoax sebagai tema yang diangkat pada PKM Sesi Ke-1, memfokuskan kajian [ada 
makna Hoax yang dibuat seseorang atau kelompok dengan beragam tujuan, mulai dari sekedar main-main, hingga tujuan ekonomi (penipuan), dan politik (propaganda/pembentukan opini publik) atau agitasi (hasutan). Hoax biasanya muncul ketika sebuah isu mencuat ke permukaan, namun banyak hal yang belum terungkap atau menjadi tanda tanya.

Di Indonesia, hoax marak sejak pemilihan presiden 2014 sebagai dampak gencarnya kampanye di media sosial. Hoax bermunculan guna menjatuhkan citra lawan politik alias kampanye hitam alias kampanye negatif. Menurut Dewan Pers, di Indonesia maraknya hoax juga karena adanya krisis kepercayaan terhadap media mainstream sehingga publik menjatuhkan ke media abalabal. Menurut Yosep Adi Prasetyo selaku Ketua Dewan Pers hoax merupakakan dampak berubahnya fungsi media sosial dari media pertemanan dan berbagi sarana menyampaikan pendapat politik dan mengomentari pendirian orang lain (Herlinda, 2019).

Beberapa ciri-ciri guna mengetahui dan memetakan berita hoax yakni adalah pelaku dalam hal ini mendistribusikan konten terssebut melalui via email atau media sosial karena efeknya lebih besar mengingat pengguna media sosial sangat besar di Indonesia. Dalam konten hoax tersebut berisikan pesan yang membuat cemas, panik para pembacanya yang nantinya dari kecemasan korbannya tersebut akan membuat korban dengan mudahnya membagikan berita hoax tersebut kepada orang lain dengan dalih memperingatkan. Dan hal tersebut akan diakhiri dengan himbauan agar si pembaca segera memforwardkan warning tersebut ke forum yang lebih luas. Hoax memanfaatkan iktikad baik si pembaca, sehingga pembaca email ini tanpa meneliti terlebih dahulu kebenaran beritanya, langsung segera menyebarkannya ke forum yang lebih luas. Akibarnya lalu lintas peredaran data di internet makin padat dengan berita yang tidak benar.

Ruri Rosmalinda (2017) dalam jurnal penelitiannya menjelaskan berkaitan dengan penyebab munculnya anomali adalah karena beberapa factor diantaranya: (1) Kemudahan bagi masayarakat dalam memiliki alat komunikasi yang modern dan murah, dalam hal ini adalah penggunaan smartphone sebagai media pencarian informasi; (2) Masyarakat mudah terpengaruh oleh isu-isu yang belum jelas tanpa memverifikasi atau mengkonfirmasi kebenaran informasi/berita tersebut, sehingga langsung melakukan tindakan share informasi yang belu jelas kebenarannya; (3) Kurangnya minat membaca, sehingga ada kecenderungan membahas berita tidak berdasarkan data akurat, hanya mengandalkan daya ingat atau sumber yang tidak jelas.

Pendekatan Hoax dengan UndangUndang Nomor 11 Tahun 2008 Tentang Informasi dan Transaksi Elektronik Undangundang Nomor 11 Tahun 2008 tentang Informasi dan Transaksi Elektronik mengatur hal-hal yang merupakan kejahatan komputer, pengertian dari Informasi elektronik dan transaksi elektronik adalah sebagai berikut Informasi Elektronik adalah satu atau sekumpulan data elektronik, termasuk, tetapi tidak terbatas pada tulisan, suara, gambar, peta, rancangan, foto, electronic data interchange (EDJ), surat elektronik (electronic mail), telegram, teleks, telecopy atau sejenisnya, huruf, tanda, angka, Kode Akses, simbol, atau perforasi yang telah diolah yang memiliki arti. atau dapat dipahami oleh orang yang mampu memahaminya. Sedangkan transaksi elektronik adalah Transaksi Elektronik adalah perbuatan hukum yang dilakukan dengan menggunakan Komputer, jaringan Komputer, dan/ atau media elektronik lainnya.

Hoax atau berita bohong diatur dalam pasal 28 Undang-Undang Nomor 11 Tahun 2008 tentang Informasi dan Transaksi Elektronik. Dalam Kutipan Undang- Undang Nomor 11 Tahun 2008 tentang Informasi dan Transaksi Elektronik, di Pasal 28 UndangUndang Nomor 11 Tahun 2008 Tentang Informasi dan Transaksi Elektronik berbunyi : (1) Setiap Orang dengan sengaja, dan tanpa hak menyebarkan berita bohong dan menyesatkan yang mengakibatkan kerugian konsumen dalam Transaksi Elektronik. (2) Setiap orang dengan sengaja dan tanpa hak menyebarkan informasi yang ditujukan untuk menimbulkan rasa kebencian atau permusuhan individu dan/atau kelompok masyarakat tertentu berdasarkan atas suku, agama, ras, dan antar golongan (SARA).

Sedangkan ancaman hukumannya sebagai berikut, Pada pasal 45 Undang- 
Undang Nomor 11 Tahun 2008 Tentang Informasi dan Transaksi Elektronik berbunyi; (1) Setiap Orang yang memenuhi unsur sebagaimana dimaksud dalam Pasal, 28 ayat (1) atau ayat (2) dipidana dengan pidana penjara paling lama 6 (enam) tahun dan/atau denda paling banyak Rp1.000.000.000,00 (satu miliar rupiah).

Dalam pasal 28 ayat 2 Undang-Undang Nomor 11 Tahun 2008 Tentang Informasi dan Transaksi Elektronik menjelaskan mengenai ujaran kebencien (hate speech). Dalam Surat Edaran Kapolri Nomor: SE/06/X/2015 dijelaskan bahwa ujaran kebencian (hate speech) dapat berupa tindak pidana yang diatur dalam Kitab Undang-Undang Hukum Pidana (KUHP) dan ketentuan pidana lainnya diluar KUHP, yang berbentuk antara lain: (a) Penghinaan; (b) pencemaran nama baik; (c) penistaan; (d) perbuatan tidak menyenangkan; (e) memprovokasi; (f) menghasut; (g) penyebaran berita bohong.

Berdasarkan Undang-Undang Nomor 11 Tahun 2008 tentang Informasi dan Transaksi Elektronik menyebarkan berita hoax merupakan suatu kejahatan dengan anacaman pidana penjara paling lama 6 (enam) bulan dan/atau denda paling banyak Rp.1000.000.000,00 (satu miliar rupiah).

Fokus problem dalam konteks hoax ini pada hakikatnya adalah dimana dalam jagad dunia maya yang banyak berserakan berita sampah, euforia dalam facebook dan twitter serta jejaring lainnya memberikan ruang untuk ajang saling menuding dan saling fitnah yang tidak disertai oleh fakta, fitnah menjadi hal yang sangat biasa dikalangan penulis dengan mengedepankan tujuan-tujuan mereka. Tidak hanya itu, berita dengan nilai nol akan ada ataupun berita-berita palsu yang disebarkan melalui jejaring sosial akan mudah tersebar dalam re-upload atau diteruskan oleh pengguna media.

Sayangnya pembaca tidak memfilter lebih lanjut tentang berita atau artikel dengan kekosongan nilai atau berita dan artikel palsu, pembaca hanya akan menyetujui jika itu sependapat dengan ideologinya dan menerima mentah-mentah terhadap apa yang dibaca dan disetujuinya, kemudian diteruskan ke publik dan akan berjalan dengan ritme yang sama, serta rejected oleh pihak yang tidak seideologi. Pemaparan tulisan dengan faktapun akan direject oleh pembaca jika tulisan tersebut tidak seideologi dengan pembaca. Ini menjadi konsekuensi yang harus diterima dan tidak boleh dikeluhkan oleh pemerintah dan masyarakat yang telah memilih demokrasi dengan penyampaian pendapat yang kebablasan. Bagaimanapun bentuk nihil dari berita hoax tidak bisa dihilangkan secara semi ataupun permanen, tugas kita selanjutnya hanyalah meminimalisir keadaan hoax dan lebih pintar dalam memilih.

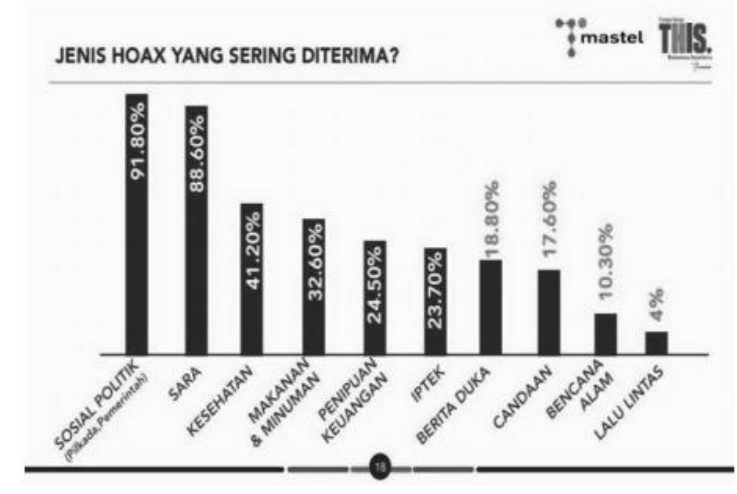

Gambar 1: Persentase Hoax yang Populer di Sebarkan

Media sosial dalam hal ini telah mendorong adanya komunitas virtual di mana anggotanya dapat berdiskusi tentang isu publik, termasuk Pilkada dan kandidat, secara rasional. Para pengguna media sosial juga tak hanya kalangan kelas menengah ke atas. Kalangan menengah ke bawah juga telah menggunakan media sosial. Pengguna media sosial itu sendiri sudahvmelebar dengan adanya smartphone dengan harga terjangkau. Menurut Cangara (2016:338-339), di Amerika media massa menjadi sumber utama informasi politik. Jika pemilih mengalami kesulitan bagaimana cara memilih dan siapa akan dipilih, mereka akan kembali kepada media. "Mass media as the primary source of political information." (Dominick,1972, Mansfield and Weaver,1982).

Hoax bisa dikemas dengan cara yang sangat halus, disertai data yang seolah-olah benar. Sehingga pembaca agak sulit mengetahuinya. Berita hoax ini memang didesain sesuain dengan kebutuhan kelompok tertentu dan mengikuti isu-isu yang sedang berkembang, sehingga publik terlena dengan perkembangan isu seolah ola berita itu benar. Dari PKM Sesi ke-1 ini diharapkan audiens dapat memahami upaya yang tepat dalam menangkal hoax dilingkungannya masingmasing. Setelah sebelumnya telah diberikan gambaran tentang ragam dan jenis-jenis hoax 
yang sering muncul di masyarakat. Sehingga audiens PKM dapat berperan aktif dilingkungannya masing-masing.

\section{b. Kajian Black Campaign}

Kampanye hitam (black campaign), sebuah cara untuk menjunjung harkat dan martabat pasangan calon dengan mempertaruhkan lawannya yang dijatuhkan. Menurut Cangara (2014) setiap usaha untuk mengisi jabatan, terutama untuk jabatan publik, maka gossip yang mengarah pada bentuk kampanye hitam selalu muncul. Kampanye hitam yang biasa disebut black campaign cenderung menyudutkan para calon yang diusung untuk menduduki suatu jabatan. Isu itu biasanya erat kaitannya dengan apa yang disebut "3Ta", yaitu : Harta, Wanita, dan Tahta. Harta biasanya diisukan dalam bentuk korupsi, wanita dalam bentuk istri simpanan atau perselingkuhan, sedangkan tahta dinilai sikap ambisius (Turistiati,2016)

Seperti sebuah ungkapan yang diungkapkan oleh Pierre Levy:

"As expressed by Pierre Levy (1997) in his book Cyberculture, the internet is an open, flexible, and dynamic informational environment that allows people to develop new knowledge orientations. People are involved in a democratic world which promotes a more interactive society-based allocation of power. The online realm acts as a meeting place of sorts for people to expand their social spheres, create opportunities for new knowledge, and offer spaces for broadly sharing different views (Soukup, 2006: 423)."

$\begin{array}{clc}\text { Bukan dipungkiri lagi bahwasanya } & \text { la } \\ \text { masyarakat Indonesia sesuai yang }\end{array}$ diungkapkan oleh Pierre Levy tersebut ketika bermain media sosial seperti Instagram, Facebook, Twitter, dan forum diskusi online seperti Kaskus, serta media percakapan (chatting) seperti Line, Whatsapp, dan Black Berry Messenger (BBM) yang mana semua media ini dikembangkan dan berkembang di dalam masyarakat dan berbentuk diskusi terbuka sehingga secara tidak langsung dapat menimbulkan paham paham maupun pengetahuan baru di dalam masyarakat dengan atau tanpa bukti yang jelas. Untuk masyarakat perkotaan kelas menengah, komunikasi politik melalui media massa sangat efektif karena pola hidup mereka yang sibuk tidak memberi mereka peluang untuk melakukan komunikasi langsung dengan orang lain. Apalagi kalau mereka tidak punya kepentingan langsung dengan sang komunikator. Bagi mereka, media massa cetak dan elektronik merupakan sarana paling efektif untuk mengetahui dan menyampaikan umpan balik setiap pesan politik yang ada.( Turistiati,2014)

Kemudahan dalam menggunakannya menjadikan media sosial digemari dan digunakan terus menerus oleh masyarakat Indonesia. Dahulu black campaign dilakukan melalui pembagian atau penyebaran informasi melalui media cetak seperti pamflet, fotokopian artikel, dan lain-lain, yang didalamnya berisikan mengenai informasiinformasi negatif pihak lawan, kepada masyarakat luas. Penyebaran itu dilakukan oleh tim sukses maupun simpatisan dari si bakal calon legislatif maupun eksekutif. Sekarang black campaign dilakukan dengan menggunakan media yang lebih canggih, seperti misalnya menggunakan sosial media dan komunikasi lewat gadget Namun demikian, media cetak pun masih tetap digunakan untuk media black campaign ini.

Pada dasarnya black campaign, terutama yang terjadi dalam pelaksanaan Pemilu ataupun Pilkada,merupakan salah satu bentuk kampanye yang terselubung. Pelaku black campaign biasanya tidak akan memperlihatkan identitas ataupun afiliasi politiknya. Isi dari black campaign pun tidak irasional dan dan tujuannya sudah pasti menjatuhkan lawan politik dengan hal-hal yang absurd dan tidak dapat dipertanggungjawabkan kebenarannya. Inti dari black campaign ini sesungguhnya adalah membangun persepsi buruk pada masyarakat akan calon yang mejadi lawan politik sehingga akibat dari persepsi yang dimunculkan itu membuat masyarakat menerima secara "bulat" isi kampanye ini, tanpa memproses isi kampanye hitam ini. Tujuan akhirnya sudah tentu berimbas pada perolehan suara dalam pemilihan.

Riswan didalam bukunya Komunikasi Politik mengatakan bahwa black campaign merupakan model kampanye dengan menggunakan rayuan yang merusak, sindiran atau rumors yang tersebar mengenai sasaran kepada para kandidat atau calon kepada masyarakat agar menimbulkan presepsi yang dianggap tidak etis terutama dalam hal kebijakan publik. Sejalan dengan 
Pendapat-pendapat para ahli seperti yang telah disebutkan di atas seperti Clevelland Ferguson (1997), Terry Cooper (1991), Kaid, Chanslor \& Hovind (1992) juga menguatkan hal tentang apa yang dimaksud dan tujuan dari black campign (riswandi, 2019).

George Carslake Thompson mengemukakan bahwa proses pembentukan opini publik dalam suatu publik yang menghadapi isu, dapat timbul berbagai kondisi yang berbeda-beda yaitu: (1) Mereka dapat setuju terhadap fakta yang ada atau mereka pun boleh tidak setuju; (2) Mereka dapat berbeda dalam perkiraan atau estimation, tetapi juga boleh tidak berbeda pandangan; (3) Perbedaan yang lain ialah bahwa mungkin mereka mempunyai sumber data yang berbeda-beda (Sastropoetro, 1990)

Peraturan tentang pelaksanaan kampanye, yang di dalamnya memuat perihal tentang pelanggaran kampanye, black campaign termasuk sanksi pidana dan denda, pada dasarnya telah diatur dalam beberapa pengaturan mengenai Pemilu dalam skala nasional dan Pilkada dalam skala lokal, yang tertuang dalam Undang-Undang, yaitu : (1) Pemilu Presiden dan Wakil Presiden, diatur dengan Undang-Undang No. 42 Tahun 2008 tentang Pemilihan Umum Presiden dan Wakil Presiden ("UU Pilpres") Ancaman pidana dan denda bagi pelaku black campaign diatur dalam Pasal 214 UU Pemilu Presiden; (2) Pemilu DPR, DPD, dan DPRD diatur dengan Undang-Undang No. 8 Tahun 2012 tentang Pemilihan Umum Anggota Dewan Perwakilan Rakyat, Dewan Perwakilan Daerah, dan Dewan Perwakilan Rakyat Daerah ("UU Pemilu Legislatif"). Ancaman pidana dan denda bagi pelaku black campaign diatur dalam Pasal 299 UU Pemilu Legislatif; (3) Khusus untuk Pemilihan Kepala Daerah dalam Pilkada Serentak Tahun 2015, Pemerintah mengeluarkan Undang-Undang No. 1 Tahun 2015 tentang Penetapan Peraturan Pemerintah Pengganti UndangUndang No. 1 Tahun 2014 Tentang Pemilihan Gubernur, Bupati, dan Walikota menjadi UU, dilanjutkan dengan dikeluarkannya UndangUndang No. 8 Tahun 2015 tentang Perubahan Atas UndangUndang No. 1 Tahun 2015 Tentang Penetapan Peraturan Pemerintah Pengganti
Undang-Undang No. 1 Tahun 2014 Tentang Pemilihan Gubernur, Bupati, dan Walikota menjadi UU. Ancaman pidana dan denda bagi pelaku black campaign diatur dalam Pasal 187 ayat 2 UU Pilkada Serentak; (4) Peraturan Komisi Pemilihan Umum No. 7 Tahun 2015 Tentang Kampanye Pemilihan Gubernur Dan Wakil Gubernur, Bupati Dan Wakil Bupati Dan/Atau Walikota Dan Wakil Walikota. Ancaman pidana dan denda bagi pelaku black campaign diatur dalam Pasal 70 ayat 1 UU Peraturan Komisi Pemilihan Umum.

Black campaign jika dikaitkan dengan konteks teori Bounded rationality adalah teori tentang perilaku manusia yang memilih karena dihadapkan pada keterbatasan kognitif, khususnya karena keterbatasan informasi tentang hal yang akan dipilih. Faktor yang menentukan adalah apa yang dinamakan dengan perilaku heuristics. Dalam konteks bounded rationality, kampanye hitam dilakukan untuk menghadirkan perilaku heuristic (menyelidiki sendiri), yang disebut dengan affect referral. Perilaku affect referral (rujukan pengaruh) terjadi ketika para pemilih memilih kandidat yang menurut mereka paling menarik secara emosional Selain itu, terdapat pula istilah familiarity (keakraban), di mana pemilih merasa ada kesamaan atau hubungan yang akrab dengan kandidat karena perilaku kandidat yang dinilai identik dengan mereka. Seorang calon presiden yang mampu menghadirkan jenis heuristic ini di kalangan pemilihnya juga akan imun terhadap kampanye hitam. Artinya, jika pemilih sebelum terjadi black campaign sudah menetapkan pilihanya atau sudah simpati dengan tokoh atau calon tertentu, maka sudah pasti akan membuat pemilih jadi panic, depresi dan bukan tidak mungkin akan menuai konflik.

Konteks dampak seperti konflik tersebutlah yang diharapkan tidak terjadi. Oleh karenanya diharapkan dalam PKM tersebut Aparat TNI dapat lebih dapat mengantisipasi kemunculan black campaign dimasyarakat dengan upaya pencegahan yakni mensosialisasi kepada masyarakat tentang upaya-upaya efektif dalam menangkal

black campaign tersebut. Dalam hal ini dampak positif yang diharapkan terjadi adalah ketertiban di masyarakat. 
Caradde: Jurnal Pengabdian Kepada Masyarakat

Vol 2 No 1, Agustus 2019
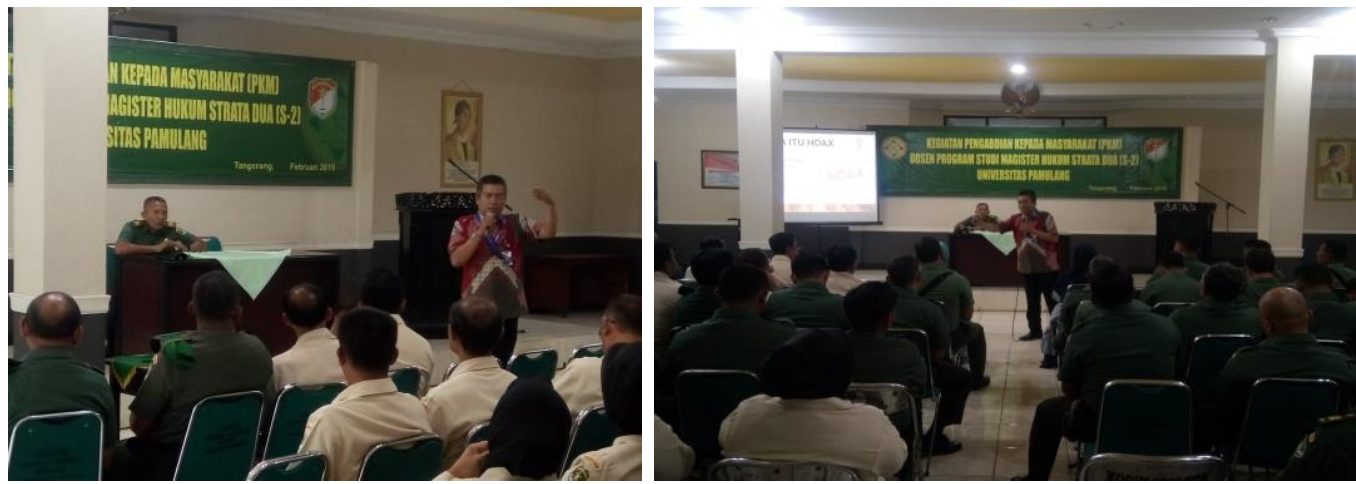

Gambar 2: Tim Memberikan Materi dalam Pelatihan PKM KODIM 0506/Tgr
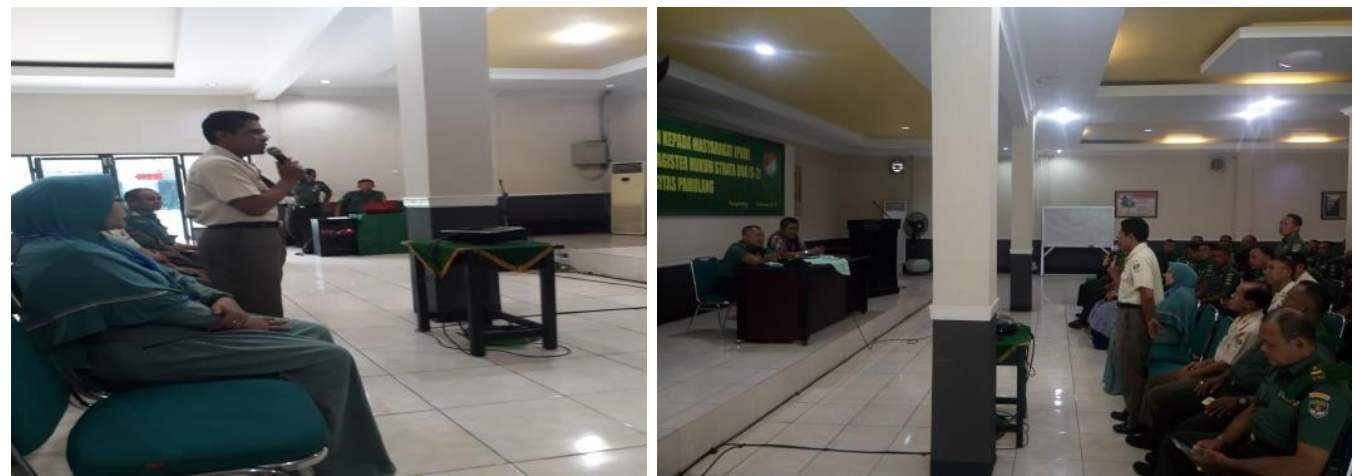

Gambar 3: Sesi Tanya Jawab PKM di KODIM 0506/Tgr

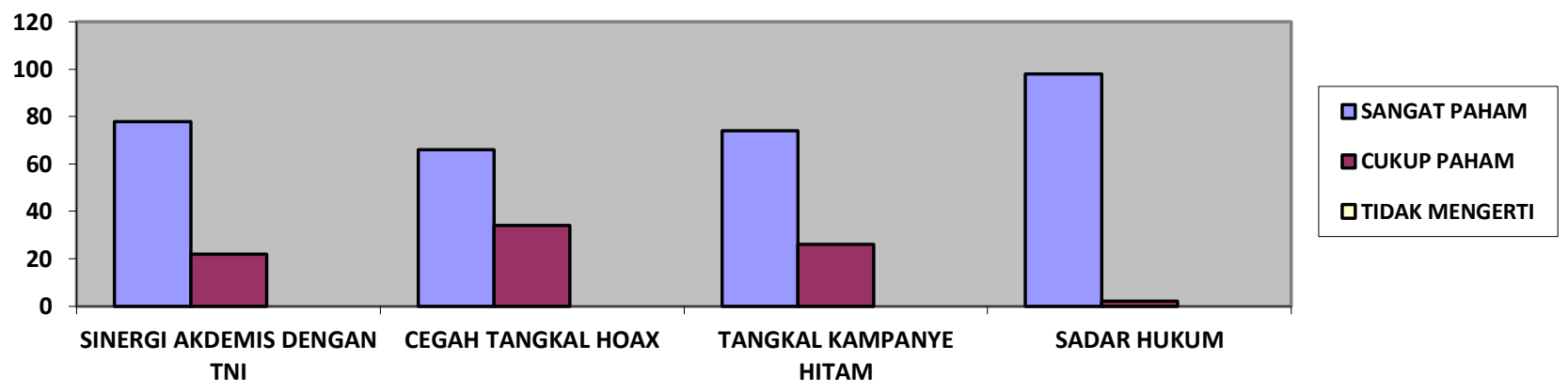

Grafik 1. Efektifitas PKM dan Persentase Pemahaman Audiens

\section{SIMPULAN DAN SARAN}

Oleh sebab hal tersebut di atas maka di dapatkan kesimpulan bahwa, Anomali Hoax sangat jamak dalam jagad dunia maya, dimana banyak berserakan berita sampah, euforia dalam facebook dan twitter serta jejaring lainnya memberikan ruang untuk ajang saling menuding dan saling fitnah yang tidak disertai oleh fakta, fitnah menjadi hal yang sangat biasa dikalangan penulis dengan mengedepankan tujuan-tujuan mereka. Tidak hanya itu, berita dengan nilai nol akan ada ataupun berita-berita palsu yang disebarkan melalui jejaring sosial akan mudah tersebar dalam re-upload atau diteruskan oleh pengguna media. Sayangnya pembaca tidak memfilter lebih lanjut tentang berita atau artikel dengan kekosongan nilai atau berita dan artikel palsu, pembaca hanya akan menyetujui jika itu sependapat dengan ideologinya dan menerima mentah-mentah terhadap apa yang dibaca dan disetujuinya, kemudian diteruskan ke publik dan akan berjalan dengan ritme yang sama, serta 
rejected oleh pihak yang tidak seideologi. Dalam Anomali Black campaign memiliki peran membangun persepsi buruk pada masyarakat akan calon yang mejadi lawan politik sehingga akibat dari persepsi yang dimunculkan itu membuat masyarakat menerima secara "bulat" isi kampanye ini, tanpa memproses isi kampanye hitam ini. Tujuan akhirnya sudah tentu berimbas pada perolehan suara dalam pemilihan. dipungkiri lagi bahwasanya masyarakat Indonesia sesuai yang diungkapkan oleh Pierre Levy tersebut ketika bermain media sosial seperti Instagram, Facebook, Twitter, dan forum diskusi online seperti Kaskus, serta media percakapan (chatting) seperti Line, Whatsapp, dan Black Berry Messenger (BBM) yang mana semua media ini dikembangkan dan berkembang di dalam masyarakat dan berbentuk diskusi terbuka sehingga secara tidak langsung dapat menimbulkan paham paham maupun pengetahuan baru di dalam masyarakat dengan atau tanpa bukti yang jelas. Untuk masyarakat perkotaan kelas menengah, komunikasi politik melalui media massa sangat efektif karena pola hidup mereka yang sibuk tidak memberi mereka peluang untuk melakukan komunikasi langsung dengan orang lain.

Berkiatan dengan Hoax, yang enjadi titik fokus hasil dari Pengabdian Masyarakat kali ini adalah masyarakat diharapkan dapat memeriksa kebenaran segala bentuk informasi yang diterima dari berbagai media sosial. Konteks yang berkaitan dengan Cara memeriksa berita palsu atau hoax yang harus di harapkan adalah, cmasyarakat mampu mencari segala referensi terkait berita yang didapatkan dari internet, atau search engine. Menanyakan kepada orang-orang yang dianggap mengetahui kebenaran berita dan melalui media massa atau media cetak, seperti: Koran, TV, dan Radio, dan Media sosial. Hoax bukan saja terjadi di Indonesia, sehingga pemerintah juga perlu mengadopsi berbagai cara dari pemerintahanan di negara lain yang juga keamanan nasionalnya terancam, akibat saluran komunikasi massa yang digunakan secara tidak bertanggungjawab. Berkaitan dengan Black campaign dalam konteks ini diharapkan Komisi Pemilihan Umum (KPU) dan Badan PEngawasan Pemilu haruslah secara konsisten menjalin kerjasama dengan segenap elmen terutama media hingga masyarakat dalam lingkup mengawal jalanya pelaksanaan tahapan kampanye. serta hukum yang mengatur berkaitan dengan Black campaign haruslah secara tegas memberikan sanksibagi pihak-pihak yang melakukan Black campaign .

\section{DAFTAR RUJUKAN}

Ade Tuti Turistiati, (2016), Fenomena Black Campaign Dalam Pemilihan Kepala Daerah 2015, Jurnal Ilmiah Ilmu Administrasi, Volume VIII, Nomor 02, 209.

Herlinda Pengertian Hoax: Asal Usul dan contohnya. http://www.komunikasipraktis.com/

Mulyana, Deddy, (2014), Metode Penelitian Kualitatif Paradigma baru Ilmu Komunikasi dan Ilmu Sosial, Bandung, Remadja Rosdakarya.

Riswandi (2009) Ilmu komunikasi, Jakarta, Graha Ilmu.

Sastropoetro. S. (1990), Komunikasi Sosial, Remaja Karya, Bandung : Remaja Karya.

Soerjono. S, (2009), Pengantar Penelitian Hukum, Jakarta, UI-Press.

KBBI Daring, https://kbbi.kemdikbud.go.id, diakses 